\title{
Investing in Diamonds
}

\author{
Luc Renneboog \\ Department of Finance, CentER, Tilburg University \\ P.O. Box 90153, 5000 LE Tilburg, The Netherlands \\ E-mail: Luc.Renneboog@uvt.nl
}

Received: March 17, 2015 Accepted: April 4, 2015

doi:10.5296/ber.v5i1.7518 URL: http://dx.doi.org/10.5296/ber.v5i1.7518

\begin{abstract}
This paper examines the risk-return characteristics of investment grade gems (white diamonds, colored diamonds and other types of gems including sapphires, rubies, and emeralds). The transactions are coming from gem auctions and span the period 1999-2012. Over our time frame, the annual nominal USD returns for white and colored diamonds amount to $8.1 \%$ and $7.4 \%$, respectively, or $5.5 \%$ and $4.8 \%$ in real terms. For a Euro investor, the returns on white and colored diamonds are about $1.3 \%$ lower than for a USD investors but the Euro returns still beat inflation by $3.5 \%$ annually. The returns for Other Gem types (rubies, emeralds and sapphires) are more volatile and somewhat lower (4.5\% annual nominal returns and $2.1 \%$ in annual real terms). Applying the hedonic regression method to the data set of auction transactions of investment grade diamonds, we are able to explain more than $95 \%$ of their price variation in white diamonds. Although the diamond returns since 1999 have been below those on gold, both white and colored diamonds have significantly outperformed the US and European stock markets, US and European real estate, US government bonds, as well as European government and corporate bonds. The reward-to-risk (Sharpe ratio) of white diamonds is very close to that of US corporate government bonds. The highest Sharpe ratio (by far) over the past 14 years was the one on gold. Still, in times of crisis investments in diamonds have shown an attractive risk-return tradeoff. In spite of a small positive correlation between the diamond and the equity markets, adding diamonds to an equity portfolio still have some diversification advantages.
\end{abstract}

Keywords: Auctions; Diamonds; Gems; Hedonic regressions; Luxury goods, Alternative investments.

JEL classification: G11; G12; Q3; Z11.

Acknowledgements: We are grateful to Filip Nys from Rocks International for providing us the data and to Tamas Barko for research assistance.

\section{Executive Summary:}

- Over the period 1999-2012, the annual nominal USD returns for white and colored diamonds amount to $8.1 \%$ and $7.4 \%$, respectively, or $5.5 \%$ and $4.8 \%$ in real terms (over and above inflation). 
- For a Euro investor, the returns on white and colored diamonds are about $1.3 \%$ lower than for a USD investors but the Euro returns still beat inflation by $3.5 \%$ annually.

- The returns for Other Gem types (rubies, emeralds and sapphires) are more volatile and somewhat lower (4.5\% annual nominal returns and $2.1 \%$ in annual real terms).

- The return generating model used to estimate the returns works well: applying the hedonic regression method to the data set of auction transactions of investment grade diamonds, we are able to explain more than $95 \%$ of their price variation in white diamonds. The model also performs well for colored diamonds. We confirm that white and colored diamonds are traded based on its physical characteristics as well as details about the transaction (location, auction house).

- Although the diamond returns since 1999 have been below those on gold (a much-used safe haven in the recent financial crisis), both white and colored diamonds have significantly outperformed the US and European stock markets, US and European real estate, US government bonds, as well as European government and corporate bonds. The reward-to-risk (Sharpe ratio) of white diamonds is very close to that of US corporate government bonds. The highest Sharpe ratio (by far) over the past 14 years was the one on gold. Still, in times of crisis investments in diamonds have shown an attractive risk-return tradeoff.

- We have also shown that in spite of a small positive correlation between the diamond and the equity markets, adding diamonds to an equity portfolio still have some diversification advantages.

\section{Introduction}

In the recent past, impressive sums of money have been spent on diamonds and other gems. In December 2008, a British jewelry dealer paid more than 24 million U.S. dollar (USD) for the 35.56 carat grayish-blue Wittelsbach Diamond at a Christie's auction in London. On 16 November 2010, a rectangular 24.78 carat pink diamond was sold in the auction rooms of Sotheby's Geneva for the record price of 45.75 million USD. In private transactions, the figures have even been higher (Bloomberg, 2008). According to some jewelry experts, the recent financial crisis is partially responsible for the elevated price levels: "nobody knows what they are buying with stocks, but here they are buying something solid and tangible" (Reuters, 2010).

Also in the late 1970s and the early 1980s - when the economic climate was arguably even more uncertain than today - there was an increased investor attention for tangible but easily storable assets, such as gold (Ibottson and Brinson, 1993), stamps (Dimson and Spaenjers, 2011), and gemstones. Two interesting examples of diamond investor manuals that were published around that time were Sutton (1979) and Dohrmann (1981). Both studies elaborated extensively on the advantages of investing in diamonds; the latter publication even claimed in its preface that "diamonds have a track record of thousands of years of value with steady, stable appreciation".

The production side of the gem industry has been dominated by the De Beers cartel since the 1870s. By stockpiling the excess supply of rough diamonds and creating an illusion of scarcity, but also by curbing attempts of speculation, the company cartel has managed to create an "orderly" primary market with prices that have been steadily increasing over time (Spar, 2006). Over the next few years, worldwide jewelry sales are expected to grow strongly, especially in emerging markets. KPMG (2010) foresees a growth in total revenues from 185 billion USD in 2010 to 230 billion USD in 2015. The Indian and Chinese market for gems 
will have surpassed the U.S. market in size by 2015.

There are two interesting aspects to the consumer demand for diamonds. First, diamonds may constitute a market for social status (Scott and Yelowitz, 2010). ${ }^{1}$ Second, and more relevant when looking at price trends, diamonds are appreciated not only because of their intrinsic consumption effects, but also because they are costly and are a store of value. This may have become even more important since the recent financial crisis. A recent Capgemini (2010) study on passion investments indeed stresses that high-net-worth individuals seek out "more tangible assets expected to hold their long-term value". As a result, "jewelry, gems, and watches' overtook 'art' as the second most important category of passion investments globally in 2009.

In this paper, we estimate the returns on diamonds and other gems in the secondary market over the period 1999-2012, using a novel data set of auction transactions. We concentrate only on the upper end of the market 'investment-grade' high-quality "white" (colorless or near-colorless) and colored diamonds, and other types of precious gemstones (sapphires, rubies, and emeralds). We also compare and relate the price trends in the secondary market for investment-grade gems to the returns on more traditional asset categories such as equity, corporate and government bonds, treasure bills, gold, and real estate.

This paper proceeds as follows. Section 2 presents the data and methodology. Section 3 illustrates the importance of time-invariant price-determining variables such as carat, color, and clarity. Section 4 outlines our price indices. Section 5 compares the performance of diamonds with that of other assets. Section 6 briefly examines whether higher-quality objects are also better investments. Section 7 concludes and discusses the need for a longer-term perspective.

\section{Data and methodology}

The data used in this study were provided by H-Ten Diamond Capital, a team of international diamond industry experts. The original database includes information on auction sales of gems at offices of Sotheby's and Christie's worldwide. Although a limited number of transactions are included for the early- and mid-1990s, we start our analysis in 1999, the first year for which there is representative coverage. In total, the database contains information on 4,750 sales. Table 1 shows the distribution of sales per half-year over the three types of stones included in the database: white diamonds, colored diamonds, and other gems. The different sorts of non-diamond gems considered are emeralds from Colombia, rubies from Burma (Myanmar), and sapphires from Burma, 'Ceylon' (Sri Lanka), and Kashmir. The panel shows that a small majority of the transacted gems are white diamonds (2,574 sales). The number of observations for colored diamonds amounts to 1,310 and that for other gemstones is 866 .

Table 1 also shows the average transaction price in Euro and USD, and the average price per carat, for each period and for each type of gem. The results indicate that the average transaction value over the past 15 years is highest for colored diamonds at Euro 505,615 (USD 642,689), followed by white diamonds at Euro 400,206 (USD 505,356 USD) and other gem stones at Euro 235,176 (USD 286,996). Also the average price paid per carat is highest for colored diamonds - at Euro 71,785 (USD 90,750). However, there is substantial time-series variation in average prices. For example, the transaction value per carat almost

\footnotetext{
${ }^{1}$ Scott and Yelowitz (2010) show that the (online) supply of diamonds has distinct discontinuities in the frequency distributions by size. Also, a diamond's price is significantly lower when its size is just below a round carat weight, such as one or two carat. This may be due to a behavioral whole numbers effect or - in the context of engagement and wedding rings - be evidence of conspicuous consumption. We do not study this (retail) segment of the diamonds market.
} 
doubled for colored and white diamonds over the period 1999-2013 (e.g. the price per carat was between Euro 20,000 and 25,000 in 1999-2002 but augmented to Euro 40,000 and 50,000 since 2010).

The increase in the price per carat for white diamonds, colored diamonds, and other gems since the early years of our time frame is further illustrated in Figure 1a (Euro) and Figure 1b (USD). 


\section{Macrothink}

Table 1. Numbers of transactions and average price levels in Euro and USD

2015, Vol. 5, No. 1

\begin{tabular}{|c|c|c|c|c|c|c|c|c|c|c|c|c|c|c|c|c|}
\hline & \multicolumn{4}{|c|}{ Number } & \multicolumn{3}{|c|}{ Average price } & \multicolumn{3}{|c|}{ Avarage price per carat } & \multicolumn{3}{|c|}{ Average price } & \multicolumn{3}{|c|}{ Avarage price per carat } \\
\hline Semester & White & Colored & Other & Total & White & Colored & Other & White & Colored & Other & White & Colored & Other & White & Colored & Other \\
\hline 1999(1) & 41 & 24 & 10 & 75 & 252,548 & 249,195 & 248,738 & 18,715 & 36,751 & 20,302 & 231,753 & 229,934 & 229,408 & 17,130 & 33,922 & 8,706 \\
\hline 1999(2) & 75 & 51 & 34 & 160 & 347,237 & 435,426 & 129,036 & 23,968 & 5,195 & 12,051 & 330,218 & 415,354 & 122,383 & 22,798 & 2,005 & 1,437 \\
\hline $2000(1)$ & 87 & 38 & 52 & 177 & 376,442 & 58,030 & 195,420 & 23,135 & 56,965 & 14,341 & 409.467 & 0.833 & 212,379 & 25,033 & & 5,539 \\
\hline $2000(2)$ & 70 & 37 & 37 & 144 & 258,058 & 414,692 & 239,704 & 19,983 & 59,492 & 15,660 & 298,504 & 479.674 & 277,384 & 23,111 & & 3,123 \\
\hline 2001(1) & 89 & 43 & 29 & 161 & 321,323 & 228,779 & 221,602 & 21,787 & 46,633 & 11,758 & 362,345 & 7.049 & 248,369 &, 544 & & 164 \\
\hline 2001(2) & 120 & 45 & 37 & 202 & 243,505 & 235,391 & 271,767 & 21,053 & 41,802 & 19,796 & 268,960 & & 301,038 & 23,239 & & 861 \\
\hline 2002 & 72 & 49 & 28 & 149 & 267,137 & & 161,614 & 19,666 & 38,609 & 14,613 & 299,324 & & 34 & 066 & & 398 \\
\hline 2002 & 70 & 46 & 19 & 135 & 212,887 & & 445 & 22,697 & 50 & 97 & 213 & & & 20 & & ,421 \\
\hline 2003 & 49 & 21 & 18 & 94 & 308,444 & & 30 & 20,519 & 20 & 35 & 277 & & & 08 & & 587 \\
\hline 2003 & 71 & 33 & 22 & 126 & 349,074 & & 45 & 26,485 & & & & & & 62 & & 963 \\
\hline 2004(1) & 88 & 57 & 30 & 175 & 375,120 & & 80 & 27,891 & & 84 & 310 & & & 015 & & 035 \\
\hline 2004(2) & 53 & 27 & 23 & 103 & 350,790 & & 264 & 26,971 & & 21 & 273,491 & & ,489 & 21,008 & & ,585 \\
\hline $2005(1)$ & 112 & 43 & 48 & 203 & 373,339 & 437 & 667 & 25,798 & 77,472 & 27,256 & 293,367 & & 250,800 & 20,346 & & 1,392 \\
\hline $2005(2)$ & 43 & 22 & 34 & 99 & 322,655 & 639 & 179,389 & 24,224 & 102,130 & 12,393 & 271,529 & 311 & 151 & 20,355 & 27 & ,509 \\
\hline $2006(1)$ & 101 & 65 & 71 & 237 & 371,682 & 547,782 & 291,371 & 32,889 & 64,549 & 24,211 & 301,395 & 447,272 & 236,449 & 26,645 & 290 & 9,688 \\
\hline $2006(2)$ & 95 & 54 & 49 & 198 & 509,626 & & 718 & 38,192 & 51,625 & 21,335 & 399,640 & 6,466 & & 29,903 & 36 & 6,739 \\
\hline 2007(1) & 92 & 60 & 43 & 195 & 415,626 & 877 & 343,579 & 36,585 & 76,489 & 22,593 & 309,751 & 508,876 & 255,718 & 27,312 & ,027 & 6,802 \\
\hline $2007(2)$ & 133 & 57 & 57 & 247 & 638,049 & & 385 & 46,477 & 115,874 & & 436,324 & & & 31,870 & 12 &, 536 \\
\hline $2008(1)$ & 86 & 51 & 41 & 178 & 817,855 & 778,011 & 316,885 & 58,728 & 86,682 & 25,316 & 523,934 & 501,560 & 203,425 & 37,669 & 5,020 & 6,235 \\
\hline $2008(2)$ & 91 & 49 & 29 & 169 & 670,503 & 920,661 & 308,912 & 52,488 & 5,426 & 15,262 & 507,783 & 703,094 & 236,789 & 39,745 & 49,385 & 1,653 \\
\hline $2009(1)$ & 111 & 36 & 37 & 184 & 465,515 & 676,261 & 48 & 40,659 & 92,984 & 03 & 347,399 & 499,243 & 131,479 & 30,353 & 68,645 & 2,066 \\
\hline $2009(2)$ & 118 & 76 & 34 & 228 & 695,173 & 65 & 65 & 49,932 & 146,550 & 33,079 & 470,415 & 16 & 280,496 & 33,817 & 3,773 & 22,335 \\
\hline $2010(1)$ & 118 & 75 & 49 & 242 & 653,831 & 50 & 34,993 & 53,040 & 145,689 & 38,489 & 503,981 & 6,330 & 334,845 & 40,876 & 114,358 & 29,443 \\
\hline $2010(2)$ & 71 & 34 & 15 & 120 & 506,044 & 1,40 & 8,833 & 58,362 & 145,653 & & 370,214 & 1,0 & 217,772 & 42,674 & 105,403 & 21,297 \\
\hline 2011(1) & 115 & 4 & 17 & 181 & 704,400 & 1,05 & & 68,422 & & & 490,198 & 580 & 678,073 & 47,695 & 113,213 & 32,215 \\
\hline 2011(2) & 81 & 32 & 2 & 115 & 888,454 & 1,53 & 2,539 & 66,912 & 237,849 & & 653,597 & $1,124,987$ & 315,179 & 49,215 & 174,498 & 11,981 \\
\hline 2012(1) & 158 & 67 & 1 & 6 & 746,579 & $1,076,882$ & $1,142,500$ & 59,042 & 144,837 & 56,531 & 575,045 &, 827 & 873,271 & 45,422 & 111,359 & 43,210 \\
\hline 2012(2) & & - & 0 & 227 & 70 & 1,03 & & 51,999 & & & & & & 40,577 & & \\
\hline Total & 2,574 & 1,310 & 866 & 4,750 & 505,356 & 642,689 & 286,996 & 39,792 & 90,750 & 21,920 & 400,206 & 505,615 & 235,176 & 31,408 & 71,785 & 17,938 \\
\hline
\end{tabular}




\section{Macrothink}

This table shows the number of observed auction transactions, the average price in nominal Euro and USD, and the average price per carat in nominal Euro and USD of white diamonds, colored diamonds, and other gems for each semester over the period 1999-2012.

\section{Figure 1. Average price / carat (nominal)}

Figure 1 shows the average price per carat in nominal Euro (Figure 1a) and USD (Figure 1b) of white diamonds, colored diamonds, and other gems for each semester over the period 1999-2012.

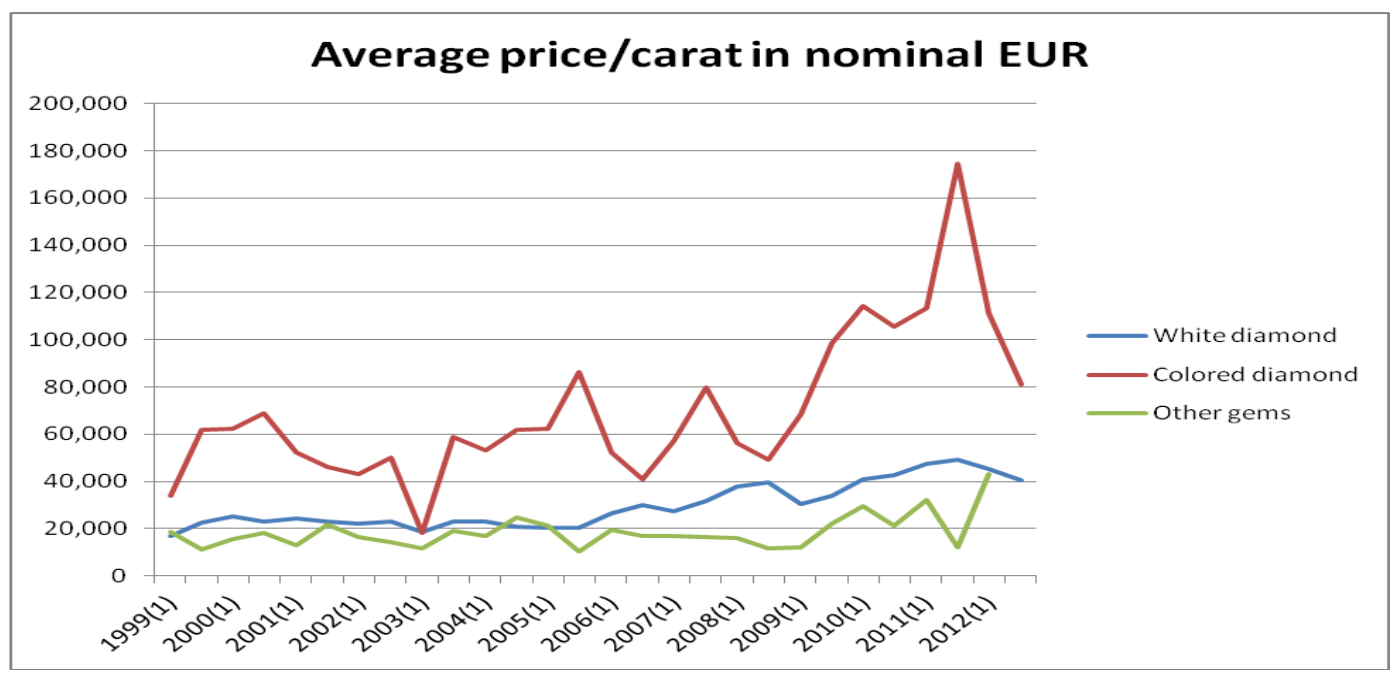

Figure 1a

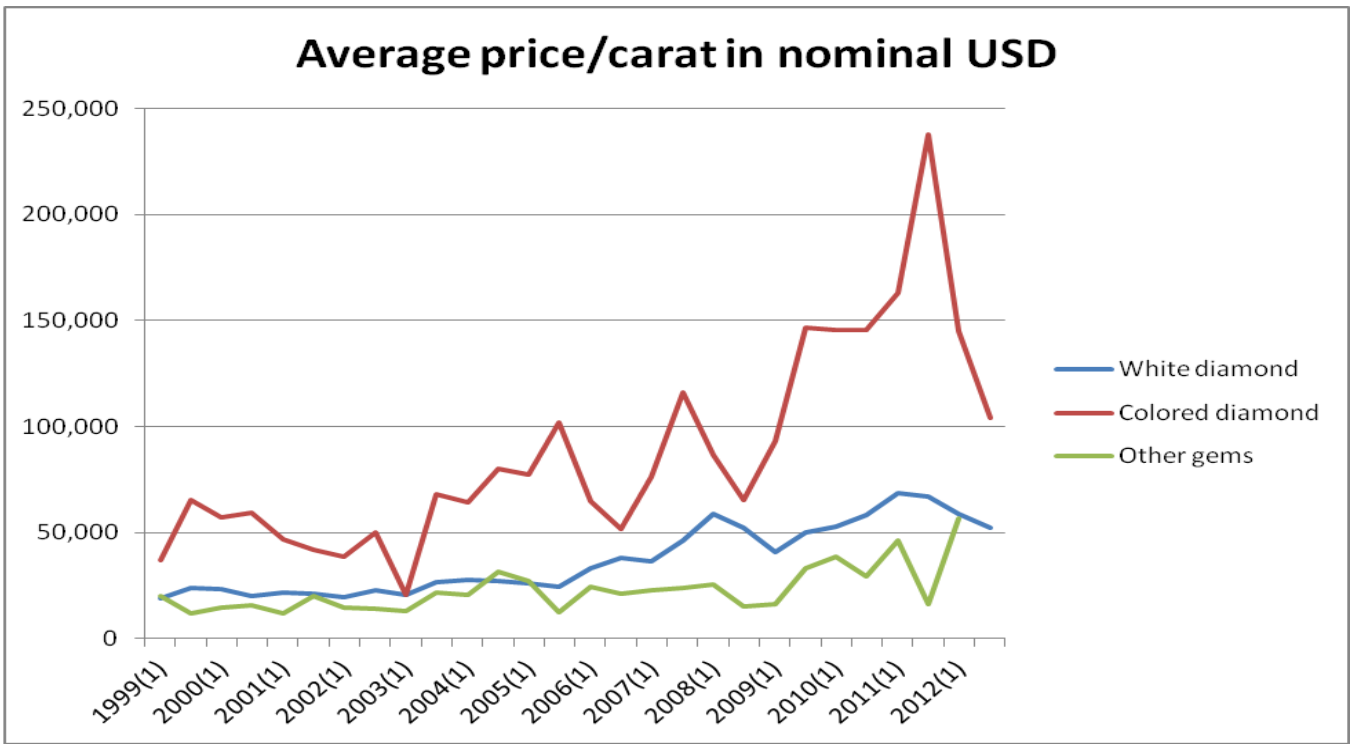

Figure 1b

Calculating average prices is only an initial step, since a price index should also take into account variation in the average quality of the items sold. Indeed, average prices can go up both because of a true increase in the overall price level, or because of a shift in the sales composition towards higher-quality objects. Dohrmann (1981) claims that the uniqueness of 
each piece implies that constructing a price index for diamonds is like "trying to have an index for snowflakes". Such a statement is incorrect: building a price index for heterogeneous goods is far from impossible, provided that enough transactions are observed and that detailed sales information is available. Index construction may even be less complicated for diamonds than for other collectible goods, since a relatively limited number of easily quantifiable characteristics capture a lot of the appeal - and hence the price - of each stone (Renneboog and Spaenjers, 2012).

In this study, we estimate the returns on gems by applying a hedonic regression to our database. The hedonic methodology has previously been used to estimate the returns on other heterogeneous and infrequently traded assets, such as real estate (e.g., Meese and Wallace, 1997), wine (e.g., Combris et al, 1997), and art (e.g., Renneboog and Spaenjers, 2013). The idea is to relate the prices of individual sales to a number of price-determining characteristics (e.g., the number of rooms in a house, the region of production of a bottle of wine, or the size of a painting) and a range of time dummies (e.g., years). Under the assumption that the hedonic characteristics capture the quality of the item, the regression coefficients on the time dummies will proxy for the price level in each period. More formally, a hedonic regression model can be represented as in Equation (1):

$$
\ln p_{k t}=\alpha+\sum_{m=1}^{M} \beta_{m} x_{m k t}+\sum_{t=1}^{T} \gamma_{t} d_{k t}+\varepsilon_{k t}
$$

where $p_{k t}$ represents the price of good $k$ at time $t, x_{m k t}$ is the value of characteristic $m$ of object $k$ at time $t$, and $d_{k t}$ is a time dummy variable which takes a value of one if good $k$ is sold in period $t$ (and zero otherwise). The coefficients $\beta_{m}$ reflect the attribution of a shadow price to each of the $M$ characteristics, while the changes in the antilogs of the coefficients $\gamma_{t}$ are used to calculate returns over $T$ time periods.

The choice of the hedonic characteristics is of key importance, since these variables should capture as precisely as possible the time-invariant quality or appeal of each item. Our database contains information on many of the characteristics that can be expected to impact gem prices (see also Renneboog and Spaenjers (2012)). We first focus on 'the four Cs', which are assumed to be the most important factors in setting the value of diamonds (and, to some extent, other gems): carat, color, clarity, and cut. The variable Ln(carat) measures the natural $\log$ of the carat weight. We have different categories of color for each type of diamonds, indicating different color spectra of light emitted. For white diamonds, our dummy categories are based on the traditional scale which goes from $\mathrm{D}$ to $\mathrm{Z}$ (If a diamond is indicated to belong to two adjacent categories, we use the greatest letter). Colorless or nearly colorless diamonds have greater brilliance. For colored diamonds, we include separate variables for blue, brown, green, pink, and yellow stones (which are the most frequently observed colors). With respect to the other gems, we create separate variables for emeralds, rubies, and for sapphires from Burma, Ceylon, and Kashmir. For the diamonds in our database, we also consider the clarity of each stone, going from flawless $(F L)$, over internally flawless $(I F)$, very very small inclusions $(V V S)$, very small inclusions $(V S)$, and small inclusions $(S I)$, to inclusions or 
unspecified clarity (Other / unknown). The inclusions are scratches, minerals, or other imperfections that have an impact on the diamond's clarity. Diamonds that are completely free from internal flaws are extremely rare. As only one colored diamond is of the "flawless" category; we pool it with the "internally flawless" stones While the color and clarity of a diamond are predetermined by nature, the cut, which affects the brilliance and sparkle, is influenced by human intervention. We take into account the shape of each diamond, by including variables capturing the most popular types of cut: Round, Emerald, Marquise, and Passion. We combine less frequently used cuts (such as princess, radiant, oval, pear, asscher) into a benchmark category called Other.

Next, in most cases, we observe the location of sale, which can be Geneva, London, Hong Kong, London, New York or another location (Other: Los Angeles, Sankt Moritz,...) in case there are less than 20 sales in a city. Finally, we also include some additional information. Christie's equals one if the stone is sold at that auction house, and thus not at Sotheby's (which we use as benchmark). Brand equals one if the jewel is from a premium brand, such as Bulgari, Cartier, Graff, or Tiffany. Certificate equals one when the database indicates that an authenticity certificate, issued by one of the specialized laboratories, accompanies the stone. (Most of the emeralds, rubies, and sapphires in our sample have a certificate, which makes the presence of a certificate not very informative.) For white diamonds, a dummy variable Potential indicates whether the diamond could be upgraded by recutting or polishing. We only use these additional variables if there are at least 20 observations that take the least frequent of the two possible values.

Table 2 shows the descriptive statistics for all variables in our set-up. We show the frequencies of occurrence of the stones' characteristics across all transactions. For the variable $\operatorname{Ln}$ (carat), we show the average value. The mean weight is highest in the category of non-diamond gems (12.9 carat) versus 7.4 for white and colored diamonds (compare Panels A-C). In the category of white diamonds (Panel A), we see that the 'colorless' diamonds with color grading D are auctioned most (with $42.5 \%$ of the trades). For colored diamonds (Panel B), the most frequently observed color is yellow (57.8\%), followed by pink (17.6\%) and blue $(11.0 \%)$. In both diamond categories (Panels A-B), we observe variation with respect to clarity, but stones with very small inclusions are the largest category. Truly flawless diamonds are very rare, even in the top segment of auctioned gems. Over the time period 1999-2012, only 109 flawless white diamonds were auctioned in addition to 594 internally flawless white diamonds (Panel A), and merely two flawless colored diamonds versus 173 internally flawless colored ones (Panel B). About one in four of the white diamonds, and one in eight of the colored diamonds have a round shape (Panels A-B). Panel C shows that sapphires are more frequently traded than both emeralds and rubies. For all three types of gems, a majority of the sales included took place at Christie's (55-60\%). Only a minority is from a renowned premium brand. Finally, we see that virtually all diamonds' origin and quality are well-documented and certified (Panels A-B).

Table 2. Descriptive statistics of white and colored diamonds and other gems

Table 2 shows the descriptive statistics of the hedonic variables included in this research. All hedonic 


\section{Macrothink}

Business and Economic Research

ISSN 2162-4860

2015, Vol. 5, No. 1

characteristics are defined in Section 2 of this paper. For the dummy variables, we present the number of sales for which the variable takes the values of zero (0) and one (1), and the proportion of ones (\% 1). For the caratage, we show the median carat weight. Panels A, B, and C show the statistics for white diamonds, colored diamonds, and other gems, respectively.

Panel A. White diamonds

\begin{tabular}{|c|c|c|}
\hline Variable & Transactions with these characteristics & $\%$ \\
\hline \multicolumn{3}{|l|}{ Size } \\
\hline Ln (Carat) & \multicolumn{2}{|l|}{ [Median is 7.4 carat] } \\
\hline \multicolumn{3}{|l|}{ Color } \\
\hline $\mathrm{D}$ & 1,094 & $42.5 \%$ \\
\hline $\mathrm{E}$ & 230 & $8.9 \%$ \\
\hline $\mathrm{F}$ & 263 & $10.2 \%$ \\
\hline $\mathrm{G}$ & 223 & $8.7 \%$ \\
\hline $\mathrm{H}$ & 236 & $9.2 \%$ \\
\hline $\mathrm{IJ}$ & 281 & $10.9 \%$ \\
\hline KL & 114 & $4.4 \%$ \\
\hline $\mathrm{MZ}$ & 125 & $4.9 \%$ \\
\hline Other & 8 & $0.3 \%$ \\
\hline \multicolumn{3}{|l|}{ Clarity } \\
\hline FL & 109 & $4.2 \%$ \\
\hline IF & 594 & $23.1 \%$ \\
\hline VVS & 663 & $25.8 \%$ \\
\hline $\mathrm{VS}$ & 928 & $36.1 \%$ \\
\hline SI & 266 & $10.3 \%$ \\
\hline Other & 14 & $0.5 \%$ \\
\hline \multicolumn{3}{|l|}{ Shape } \\
\hline Emerald cut & 744 & $28.9 \%$ \\
\hline Marquise cut & 214 & $8.3 \%$ \\
\hline Passion cut & 418 & $16.2 \%$ \\
\hline Round cut & 639 & $24.8 \%$ \\
\hline Other & 559 & $21.7 \%$ \\
\hline \multicolumn{3}{|l|}{ Location } \\
\hline Geneva & 782 & $30.4 \%$ \\
\hline Hong Kong & 627 & $24.4 \%$ \\
\hline London & 46 & $1.8 \%$ \\
\hline New York & 916 & $35.6 \%$ \\
\hline Other & 203 & $7.9 \%$ \\
\hline \multicolumn{3}{|c|}{ Additional information } \\
\hline Christie's & 1,479 & $57.5 \%$ \\
\hline Brand & 372 & $14.5 \%$ \\
\hline Certified & 2,429 & $94.4 \%$ \\
\hline Potential & 158 & $6.1 \%$ \\
\hline
\end{tabular}


Panel B. Colored diamonds

\begin{tabular}{|c|c|c|}
\hline Variable & Transactions with these characteristics & $\%$ \\
\hline \multicolumn{3}{|l|}{ Size } \\
\hline Ln (Carat) & \multicolumn{2}{|l|}{ [median is 7.4 carat] } \\
\hline \multicolumn{3}{|l|}{ Color } \\
\hline Blue & 144 & $11.0 \%$ \\
\hline Brown & 89 & $6.8 \%$ \\
\hline Green & 33 & $2.5 \%$ \\
\hline Pink & 230 & $17.6 \%$ \\
\hline Yellow & 757 & $57.8 \%$ \\
\hline Other & 57 & $4.4 \%$ \\
\hline \multicolumn{3}{|l|}{ Clarity } \\
\hline FL & 2 & $0.2 \%$ \\
\hline IF & 173 & $13.2 \%$ \\
\hline VVS & 288 & $22.0 \%$ \\
\hline VS & 549 & $41.9 \%$ \\
\hline SI & 173 & $13.2 \%$ \\
\hline Other & 125 & $9.5 \%$ \\
\hline \multicolumn{3}{|l|}{ Shape } \\
\hline Cushion cut & 155 & $11.8 \%$ \\
\hline Emerald cut & 194 & $14.8 \%$ \\
\hline Passion cut & 192 & $14.7 \%$ \\
\hline Radiant cut & 300 & $22.9 \%$ \\
\hline Round cut & 179 & $13.7 \%$ \\
\hline Other & 290 & $22.1 \%$ \\
\hline \multicolumn{3}{|l|}{ Location } \\
\hline Geneva & 397 & $30.3 \%$ \\
\hline Hong Kong & 352 & $26.9 \%$ \\
\hline London & 11 & $0.8 \%$ \\
\hline New York & 431 & $32.9 \%$ \\
\hline Other & 119 & $9.1 \%$ \\
\hline \multicolumn{3}{|c|}{ Additional information } \\
\hline Christie's & 717 & $54.7 \%$ \\
\hline Brand & 111 & $8.5 \%$ \\
\hline Certified & 1,265 & $96.6 \%$ \\
\hline
\end{tabular}


Panel C. Other gems

\begin{tabular}{|c|c|c|}
\hline Variable & Transactions with these characteristics & $\%$ \\
\hline \multicolumn{3}{|l|}{ Size } \\
\hline Ln (Carat) & \multicolumn{2}{|l|}{ [median is 12.9 carat] } \\
\hline \multicolumn{3}{|l|}{ Color } \\
\hline Emerald & 183 & $21.1 \%$ \\
\hline Ruby & 151 & $17.4 \%$ \\
\hline Sapphire & 532 & $61.4 \%$ \\
\hline \multicolumn{3}{|l|}{ Location } \\
\hline Geneva & 362 & $41.8 \%$ \\
\hline Hong Kong & 152 & $17.6 \%$ \\
\hline London & 11 & $1.3 \%$ \\
\hline New York & 255 & $29.4 \%$ \\
\hline Other & 86 & $9.9 \%$ \\
\hline \multicolumn{3}{|c|}{ Additional information } \\
\hline Christie's & 501 & $57.9 \%$ \\
\hline Brand & 199 & $23.0 \%$ \\
\hline
\end{tabular}

\section{The Price Determinants of Gems}

The shadow prices of the hedonic characteristics - represented by the vector of coefficients $\beta$ in Equation (1) - are assumed to stay constant over time. This is a fair assumption given that our estimation time frame is relatively short. We estimate the model of equation (1) for each of the three types of stones four times using ordinary least squares (OLS): for nominal and real prices, both in Euro and USD. Before examining the estimated returns, we focus on the results on the hedonic variables, which are shown in Table 3 for the nominal price model in Euro. The estimated hedonic coefficients hardly differ in the alternative estimations (real prices in Euro or USD or nominal prices in USD). To avoid multicollinearity, we have to leave out one dummy variable for some groups of variables (which then serves as benchmark against which the marginal effects are calculated). For the included variables, we do not only report the coefficient, the standard deviation, and the t-statistic, but also the percentage price impact of the variable, which can be calculated as one minus the exponent of the coefficient. This enables us to focus on the economic significance of the hedonic variables.

Table 3 shows that many of our hedonic variables have a substantial impact on prices. The impact of caratage differs between the different types of stones, but in general there is a very strong relationship between weight and price (Panels A-C). If we omit the squared term from the three models, the coefficients on Ln(carat) are all above one, indicating that in general prices increase more than proportionately with carat value (not reported). For white diamonds (Panel A), we see that prices move with the color and clarity scales. For example, a diamond of color category $E$ sells on average at a $19.7 \%$ discount compared to an otherwise similar diamond of color category $D$ (the left-out category); this discount increases to more than $80 \%$ 


\section{Macrothink}

Business and Economic Research

ISSN 2162-4860

for lower-quality stones. The average premium for a flawless diamond over an internally flawless $(F L)$ diamond is $17.9 \%$. Relative to an internally flawless white diamond, a flawless white diamond is sold for a premium of $20 \%$, but a diamond with very very small inclusions $(V V S)$ incurs a discount of $27.2 \%$. Also for colored diamonds (Panel B), color and clarity play important roles. The most expensive colored diamonds are blue; they cost in general more than twice as much as green diamonds, more than three times as much as pink ones, more than eight times the value of the common yellow diamonds, and more than twelve times the value of other (brown, orange) diamonds (panel B). 


\section{Macrothink}

Business and Economic Research

ISSN 2162-4860

2015, Vol. 5, No. 1

Table 3. Regression results hedonic variables

Table 3 shows the results (coefficients, standard deviations, and t-statistics) of the OLS estimation of hedonic regression equation (1) in nominal Euro. All hedonic characteristics are defined in Section 2 of this paper. For the dummy variables, we also report the price impact, calculated as one minus the exponent of the coefficient. Panels A, B, and C show the results for white diamonds, colored diamonds, and other gems, respectively.

Panel A. White diamonds

\begin{tabular}{|c|r|r|r|r|}
\hline Variables & \multicolumn{1}{|c|}{ Coeff. } & Stan.Dev. & $t$-stat & Impact \\
\hline Size & & & & \\
\hline Ln(Carat) & 2.209 & 0.048 & 45.64 & $810.7 \%$ \\
\hline Ln(Carat)2 & -0.155 & 0.010 & -15.61 & $-14.4 \%$ \\
\hline Color & & & & \\
\hline D & benchmark & & & \\
\hline E & -0.219 & 0.020 & -10.71 & $-19.7 \%$ \\
\hline F & -0.346 & 0.020 & -17.36 & $-29.2 \%$ \\
\hline G & -0.554 & 0.021 & -26.15 & $-42.5 \%$ \\
\hline H & -0.745 & 0.021 & -35.66 & $-52.5 \%$ \\
\hline I-J & -1.038 & 0.020 & -51.38 & $-64.6 \%$ \\
\hline K-L & -1.418 & 0.029 & -48.44 & $-75.8 \%$ \\
\hline M-Z & -1.790 & 0.030 & -58.95 & $-83.3 \%$ \\
\hline Other & -1.628 & 0.099 & -16.53 & $-80.4 \%$ \\
\hline Clarity & & & & \\
\hline FL & 0.176 & 0.029 & 6.01 & $19.2 \%$ \\
\hline IF & benchmark & & & \\
\hline VVS & -0.272 & 0.017 & -16.32 & $-23.8 \%$ \\
\hline VS & -0.417 & 0.017 & -24.44 & $-34.1 \%$ \\
\hline SI & -0.751 & 0.022 & -33.64 & $-52.8 \%$ \\
\hline Other & -1.010 & 0.074 & -13.69 & $-63.6 \%$ \\
\hline Shape & & & & \\
\hline Round cut & 0.204 & 0.016 & 12.52 & $22.6 \%$ \\
\hline Emerald cut & -0.015 & 0.016 & -0.93 & $-1.4 \%$ \\
\hline Marquise cut & -0.083 & 0.022 & -3.78 & $-8.0 \%$ \\
\hline Passion cut & 0.006 & 0.018 & 0.31 & $0.6 \%$ \\
\hline Other & benchmark & & & \\
\hline Location & & & & \\
\hline Geneva & benchmark & & & \\
\hline London & 0.067 & 0.042 & 1.58 & $6.9 \%$ \\
\hline Hong Kong & 0.117 & 0.016 & 7.23 & $12.4 \%$ \\
\hline New York & -0.027 & 0.014 & -1.89 & $-2.6 \%$ \\
\hline Other & -0.038 & 0.023 & -1.69 & $-3.7 \%$ \\
\hline Additional information & & & & \\
\hline Christie's & 0.023 & 0.011 & 2.06 & $2.4 \%$ \\
\hline Brand & 0.064 & 0.016 & 4.06 & $6.6 \%$ \\
\hline Certified & -0.016 & 0.027 & -0.59 & $-1.6 \%$ \\
\hline Adjusted R-squared & 0.94 & & & \\
\hline N & 2.574 & & & \\
\hline
\end{tabular}


Panel B. Colored diamonds

\begin{tabular}{|c|c|c|c|c|}
\hline Variables & Coeff. & Stan. Dev. & $t$-stat & Impact \\
\hline \multicolumn{5}{|l|}{ Size } \\
\hline Ln(Carat) & 0.639 & 0.098 & 6.50 & $89.5 \%$ \\
\hline $\operatorname{Ln}(\text { Carat })^{\wedge} 2$ & 0.060 & 0.021 & 2.82 & $6.2 \%$ \\
\hline \multicolumn{5}{|l|}{ Color } \\
\hline Blue & 2.244 & 0.086 & 26.05 & $843.4 \%$ \\
\hline Brown & -0.659 & 0.098 & -6.74 & $-48.3 \%$ \\
\hline Green & 1.444 & 0.152 & 9.53 & $323.7 \%$ \\
\hline Pink & 1.340 & 0.067 & 19.92 & $282.0 \%$ \\
\hline Yellow & benchmark & & & \\
\hline Other & 0.551 & 0.118 & 4.65 & $73.5 \%$ \\
\hline \multicolumn{5}{|l|}{ Clarity } \\
\hline FL & 1.220 & 0.585 & 2.09 & $238.8 \%$ \\
\hline IF & benchmark & & & \\
\hline VVS & -0.265 & 0.081 & -3.28 & $-23.3 \%$ \\
\hline VS & -0.297 & 0.074 & -4.03 & $-25.7 \%$ \\
\hline SI & -0.476 & 0.092 & -5.16 & $-37.9 \%$ \\
\hline Other & -0.677 & 0.102 & -6.60 & $-49.2 \%$ \\
\hline \multicolumn{5}{|l|}{ Shape } \\
\hline Round cut & 0.117 & 0.080 & 1.47 & $12.5 \%$ \\
\hline Emerald cut & 0.331 & 0.078 & 4.26 & $39.2 \%$ \\
\hline Cushion cut & 0.191 & 0.085 & 2.25 & $21.0 \%$ \\
\hline Passion cut & 0.120 & 0.079 & 1.52 & $12.8 \%$ \\
\hline Radiant cut & -0.102 & 0.072 & -1.43 & $-9.7 \%$ \\
\hline Other cut & benchmark & & & \\
\hline \multicolumn{5}{|l|}{ Location } \\
\hline Geneva & benchmark & & & \\
\hline London & -0.111 & 0.260 & -0.43 & $-10.5 \%$ \\
\hline Hong Kong & 0.029 & 0.066 & 0.44 & $3.0 \%$ \\
\hline New York & -0.189 & 0.062 & -3.05 & $-17.2 \%$ \\
\hline Other & -0.011 & 0.090 & -0.12 & $-1.1 \%$ \\
\hline \multicolumn{5}{|c|}{ Additional information } \\
\hline Christie's & 0.003 & 0.048 & 0.06 & $0.3 \%$ \\
\hline Brand & 0.118 & 0.083 & 1.43 & $12.5 \%$ \\
\hline Certified & 0.480 & 0.132 & 3.62 & $61.6 \%$ \\
\hline Adjusted R-squared & 0.58 & & & \\
\hline $\mathrm{N}$ & 1,310 & & & \\
\hline
\end{tabular}


Panel C. Other gems

\begin{tabular}{|c|c|c|c|c|}
\hline Variables & Coeff. & Stan.Dev. & $t$-stat & Impact \\
\hline \multicolumn{5}{|l|}{ Size } \\
\hline Ln(Carat) & 0.865 & 0.237 & 3.64 & $137.5 \%$ \\
\hline $\operatorname{Ln}(\text { Carat })^{\wedge} 2$ & -0.066 & 0.041 & -1.61 & $-6.4 \%$ \\
\hline \multicolumn{5}{|l|}{ Color/type } \\
\hline Emerald & Benchmark & & & \\
\hline Ruby & 0.585 & 0.094 & 6.23 & $79.6 \%$ \\
\hline Sapphire & -0.452 & 0.075 & -6.06 & $-36.4 \%$ \\
\hline \multicolumn{5}{|l|}{ Location } \\
\hline London & -0.114 & 0.264 & -0.43 & $-10.8 \%$ \\
\hline Hong Kong & 0.290 & 0.087 & 3.32 & $33.7 \%$ \\
\hline New York & -0.035 & 0.072 & -0.48 & $-3.4 \%$ \\
\hline Other & -0.32 & 0.105 & -3.03 & $-27.4 \%$ \\
\hline \multicolumn{5}{|c|}{ Additional information } \\
\hline Christies & 0.084 & 0.062 & 1.35 & $8.7 \%$ \\
\hline Brand & 0.104 & 0.070 & 1.49 & $10.9 \%$ \\
\hline Adjusted R-squared & 0.27 & & & \\
\hline $\mathrm{N}$ & 866 & & & \\
\hline
\end{tabular}

Relative to internally flawless (IF) coloured diamonds, diamonds with very small inclusions, very small inclusions, or small inclusions are traded with discounts of relatively $23 \%, 26 \%$ and $38 \%$. We also document in Panel A that there is a significant premium of more than $20 \%$ for a round shape in the case of white diamonds. Dundek (2009) argues that "round brilliant diamonds are the only shape to have the perfect proportions defined. This shape has set the standard for all other diamond shapes." But this argument does not hold for colored diamonds (Panel B) of which emerald and cushion cuts seem to be preferred. With respect to the other gem stone types (Panel C), we observe that rubies are clearly more expensive than the other types of stones. Rubies are $80 \%$ more expensive than emeralds, which in turn are three times as expensive as sapphires. There is a strong difference in price between the different types of sapphires: the ones coming from Kashmir are significantly more expensive than the ones from Burma or Ceylon (not shown). White diamonds (Panel A) sell at slightly higher prices in London and Hong Kong than in Geneva, New York, and the other locations. Colored diamonds and other types of gems (Panels B and C) are especially expensive in Hong Kong, followed by Geneva. However, it is important to note that the pricing differences between locations may reflect otherwise unobservable differences in average quality, rather than violations of the law of one price. (Moreover, the pricing differences between locations are relatively small such that arbitrage opportunities between locations would not be exploitable.) We find no statistically significant difference in prices that the different auction houses (Christie's and Sotheby's) obtain (Panels A-C). There are only relatively small premia for jewels created by renowned designer houses: $6.6 \%$ for white diamonds (Panel A), $12.5 \%$ for colored diamonds (Panel B) and 10.9\% for other gems (Panel C). Substantially lower prices 


\section{Macrothink}

Business and Economic Research

ISSN 2162-4860

2015, Vol. 5, No. 1

are paid for the few colored stones that do not seem to have a certificate (Panel B). Finally, we see a premium of more than $20 \%$ for white stones that have the potential to be recut and upgraded (not shown).

At the bottom of each panel, we show the R-squared of each model. We find that our time dummies and hedonic characteristics together explain almost $97 \%$ of the variation in prices of white diamonds (Panel A). This implies that investment grade diamonds are large traded on their physical characteristics. The explanatory power is somewhat lower for colored diamonds and for other gems, although still at about 55\% or more (Panel B). With regard to the other gems (rubies, sapphires, and emeralds), the hedonic variables only explain $23 \%$ of the price variation (Panel C).

In Figure 2, we graphically illustrate the importance of color and clarity for white diamonds. Panel A shows the relative pricing differences between D-grade diamonds and other color grades, all else equal. Panel B shows the premium or discount for different types of clarity in comparison to an otherwise identical internally flawless $(I F)$ diamond. 
Figure 2. Importance of color and clarity for white diamonds

Figure 2 shows the relative pricing differences between white diamonds of different color grades (Figure 2a) and clarity types (Figure $2 \mathrm{~b}$ ). The percentage premiums or discounts relative to the base categories (color grade $D$ in Panel A and clarity type IF in Panel B) come from the hedonic regression output shown in Table 3.

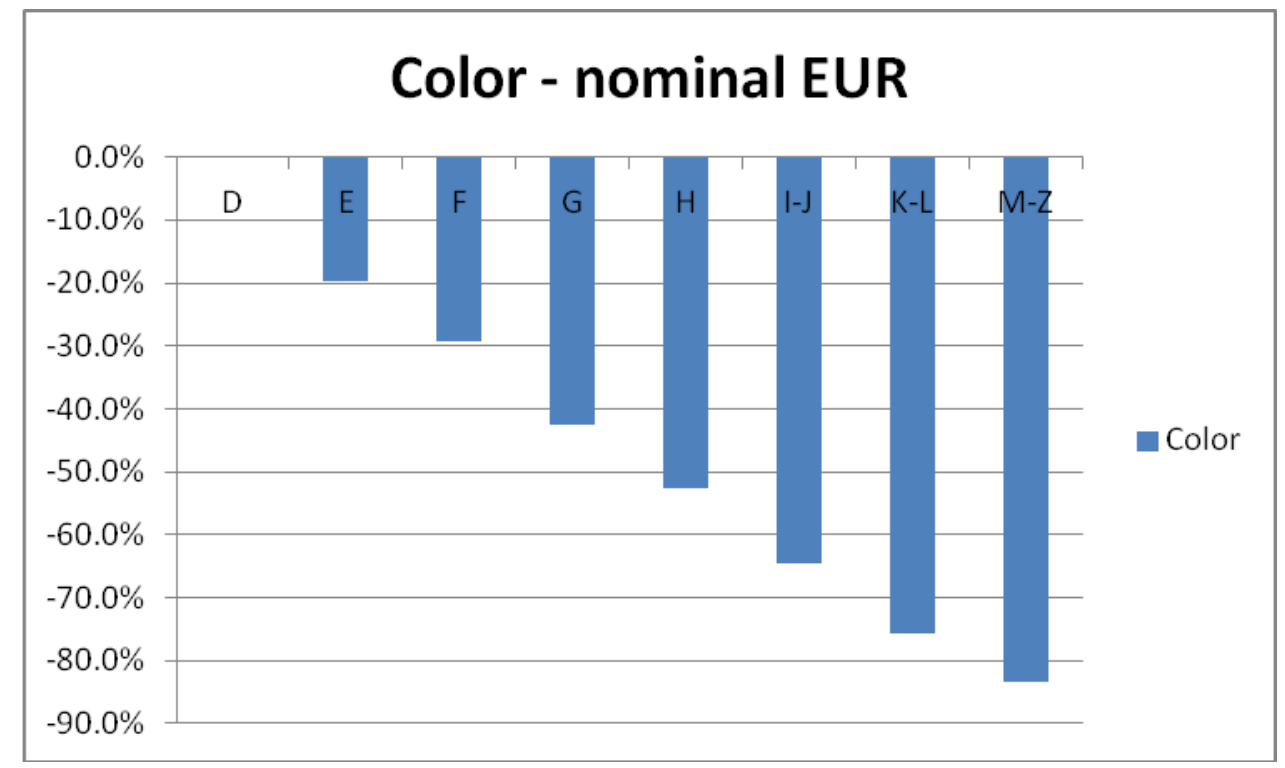

Figure 2a. Color

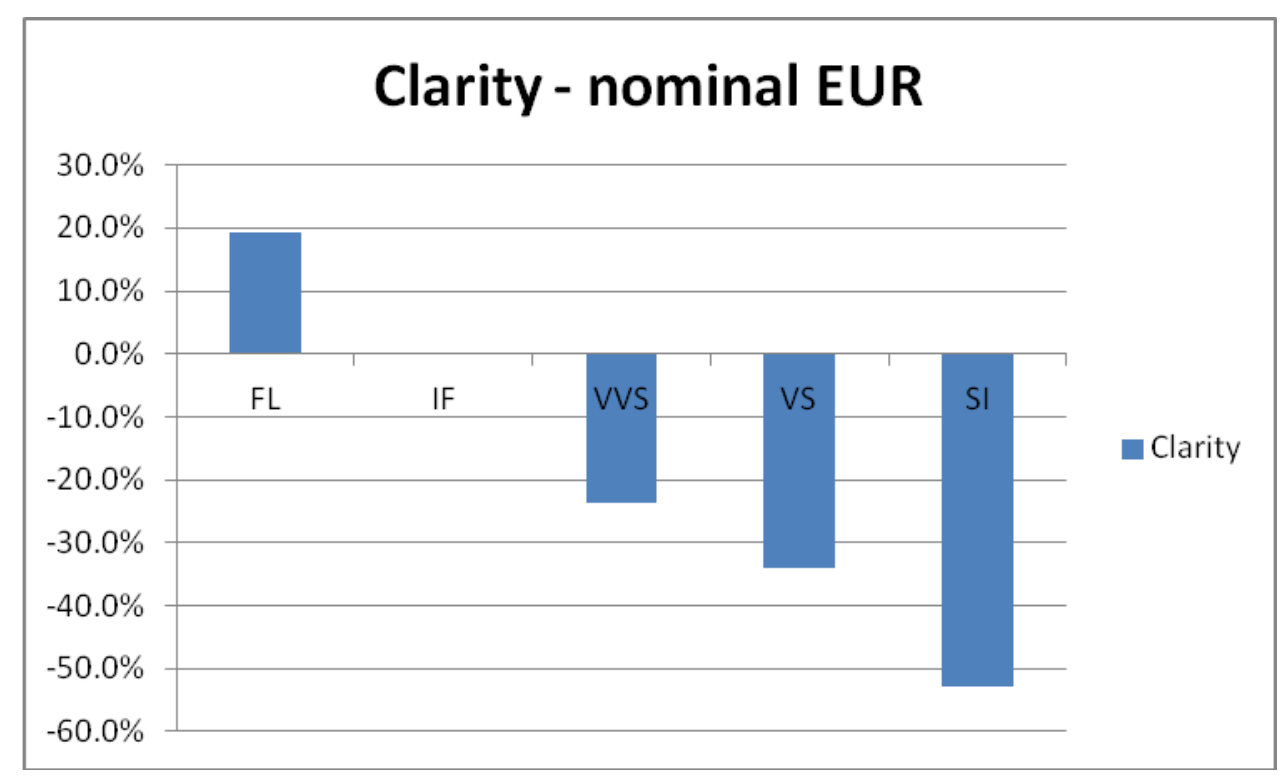

Figure 2b. Clarity 


\section{The Returns on Diamonds and Gems}

In Table 4, we show the nominal returns for each type of gem in Euro (Panel A) and USD (Panel B). At the end of each panel, we also show the real (deflated) returns. These returns are calculated as the exponent of the difference between the coefficients $\gamma$ on the time dummy variables in two subsequent periods, minus one. A caveat for the Other Gems category is needed: the returns for this category over the period 1999-2002 are based on a small number of observations and should therefore be considered with caution; from the second semester of 2003, a sufficiently large number of transactions yield more representative returns for Other Gems. We also construct a price index for each category, with the relative price level in the first semester of 1999 set equal to 100.

For white diamonds, we observe an annualized nominal return for a Euro investor of $6.9 \%$ between the first half of 1999 and the end of 2012 and of 9.7\% since 2003 (Panel A). Negative nominal returns were recorded in a number of time periods following the dot-com bust in early 2000 and during the middle of the recent financial crisis. These negative returns were more than compensated, however, by solid price rises subsequent to the crisis periods, namely between end-2003 and early-2008 and since 2009, when also equity markets performed well. The results suggest that changes in the equity market impact the funds available for investment in collectibles markets; we will examine the relationship between equity and diamond prices more thoroughly in the next section. Despite the financial crisis of 2007-2008, the annualized return after inflation on white diamonds equals $4.2 \%$ over the last 15 years and $7.1 \%$ since the second half of 2003. For a USD investors, the situation looks more favourable (Panel B). His white diamond investments could have yielded $8.1 \%$ nominally and $5.5 \%$ in real terms (both returns would be $3 \%$ higher in case his initial investment was done in 2003).

The performance of colored diamonds is just a little lower. The average nominal returns equal 6.1\% since 1999 and $7.6 \%$ since 2003 for a Euro investor whose real returns amount to respectively $3.5 \%$ and $5.0 \%$ (Panel A). As before, a dollar investor would have been able to reach somewhat higher annual returns (Panel B). The returns for Other Gem stones are the lowest but still beats inflation by an annualized $0.4 \%$ (since 1999) and $2.3 \%$ (since 2003) for investments in Euro and by respectively $2.1 \%$ and $4.1 \%$ in USD. 
Table 4. Real returns and index values

Table 4 shows the nominal and real in Euro (Panel A) and USD (panel B), which follow from the OLS estimation of hedonic regression equation (1), for white diamonds, colored diamonds, and other gems for each semester over the period 1999-2012. The panel also report the index values, where the index is set equal to 100 in the first semester of 1999. The single transaction (representing an extreme outlier) for other gems in 2012 was not included in the returns calculation.

\begin{tabular}{|c|c|c|c|c|c|c|}
\hline \multicolumn{7}{|l|}{ Panel A (in Euro) } \\
\hline \multirow[b]{2}{*}{ Year (semester) } & \multicolumn{3}{|c|}{ Nominal returns (Euro) } & \multicolumn{3}{|c|}{ Index values (Euro) } \\
\hline & White & Colored & Other Gems & White & Colored & Other Gems \\
\hline 1999(1) & & & & $100.0 \%$ & $100.0 \%$ & $100.0 \%$ \\
\hline 1999(2) & $20.5 \%$ & $53.4 \%$ & $-15.1 \%$ & $120.5 \%$ & $153.4 \%$ & $84.9 \%$ \\
\hline $2000(1)$ & $13.9 \%$ & $-25.6 \%$ & $13.3 \%$ & $137.2 \%$ & $114.2 \%$ & $96.2 \%$ \\
\hline $2000(2)$ & $1.0 \%$ & $48.2 \%$ & $1.0 \%$ & $138.6 \%$ & $169.3 \%$ & $97.2 \%$ \\
\hline 2001(1) & $4.8 \%$ & $-14.3 \%$ & $4.8 \%$ & $145.3 \%$ & $145.1 \%$ & $101.9 \%$ \\
\hline 2001(2) & $-8.9 \%$ & $-22.6 \%$ & $0.0 \%$ & $132.4 \%$ & $112.3 \%$ & $101.9 \%$ \\
\hline 2002(1) & $1.8 \%$ & $8.9 \%$ & $5.7 \%$ & $134.8 \%$ & $122.3 \%$ & $107.7 \%$ \\
\hline $2002(2)$ & $-10.7 \%$ & $-13.2 \%$ & $-39.7 \%$ & $120.4 \%$ & $106.2 \%$ & $64.9 \%$ \\
\hline 2003(1) & $-15.6 \%$ & $-15.3 \%$ & $19.9 \%$ & $101.6 \%$ & $90.0 \%$ & $77.8 \%$ \\
\hline 2003(2) & $4.6 \%$ & $28.1 \%$ & $27.1 \%$ & $106.3 \%$ & $115.3 \%$ & $98.9 \%$ \\
\hline 2004(1) & $-2.6 \%$ & $-8.6 \%$ & $-13.1 \%$ & $103.5 \%$ & $105.4 \%$ & $85.9 \%$ \\
\hline 2004(2) & $7.1 \%$ & $20.4 \%$ & $15.7 \%$ & $110.8 \%$ & $126.9 \%$ & $99.4 \%$ \\
\hline $2005(1)$ & $21.5 \%$ & $14.3 \%$ & $-1.9 \%$ & $134.6 \%$ & $145.1 \%$ & $97.5 \%$ \\
\hline $2005(2)$ & $10.0 \%$ & $20.4 \%$ & $-15.8 \%$ & $148.1 \%$ & $174.7 \%$ & $82.1 \%$ \\
\hline $2006(1)$ & $10.7 \%$ & $-8.8 \%$ & $14.9 \%$ & $164.0 \%$ & $159.3 \%$ & $94.3 \%$ \\
\hline $2006(2)$ & $2.7 \%$ & $-9.9 \%$ & $-22.7 \%$ & $168.5 \%$ & $143.5 \%$ & $72.9 \%$ \\
\hline $2007(1)$ & $9.9 \%$ & $12.5 \%$ & $43.5 \%$ & $185.2 \%$ & $161.4 \%$ & $104.6 \%$ \\
\hline $2007(2)$ & $1.7 \%$ & $7.7 \%$ & $-8.4 \%$ & $188.3 \%$ & $173.9 \%$ & $95.8 \%$ \\
\hline $2008(1)$ & $31.3 \%$ & $-8.5 \%$ & $10.3 \%$ & $247.3 \%$ & $159.1 \%$ & $105.7 \%$ \\
\hline $2008(2)$ & $-12.0 \%$ & $-7.7 \%$ & $-22.2 \%$ & $217.7 \%$ & $146.8 \%$ & $82.2 \%$ \\
\hline 2009(1) & $-13.5 \%$ & $0.5 \%$ & $-17.3 \%$ & $188.3 \%$ & $147.5 \%$ & $68.0 \%$ \\
\hline $2009(2)$ & $-4.6 \%$ & $0.9 \%$ & $94.6 \%$ & $179.6 \%$ & $148.8 \%$ & $132.3 \%$ \\
\hline $2010(1)$ & $27.1 \%$ & $15.7 \%$ & $27.5 \%$ & $228.3 \%$ & $172.2 \%$ & $168.7 \%$ \\
\hline $2010(2)$ & $-5.4 \%$ & $2.7 \%$ & $-47.5 \%$ & $216.0 \%$ & $176.9 \%$ & $88.6 \%$ \\
\hline 2011(1) & $6.1 \%$ & $11.2 \%$ & $145.1 \%$ & $229.1 \%$ & $196.7 \%$ & $217.2 \%$ \\
\hline 2011(2) & $5.5 \%$ & $8.3 \%$ & $-33.8 \%$ & $241.7 \%$ & $213.1 \%$ & $143.7 \%$ \\
\hline 2012(1) & $8.3 \%$ & $-12.7 \%$ & & $261.8 \%$ & $186.1 \%$ & \\
\hline 2012(2) & $-6.5 \%$ & $19.9 \%$ & & $244.8 \%$ & $223.2 \%$ & \\
\hline \multicolumn{3}{|c|}{ Nominal average return (geometric) since 1999(1) - Euro } & & $6.9 \%$ & $6.1 \%$ & $2.9 \%$ \\
\hline \multicolumn{3}{|c|}{ Nominal average return (geometric) since 2003(2) - Euro } & & $9.7 \%$ & $7.6 \%$ & $4.8 \%$ \\
\hline \multicolumn{3}{|c|}{ Real average return (geometric) since 1999(1) - Euro } & & $4.2 \%$ & $3.5 \%$ & $0.4 \%$ \\
\hline \multicolumn{3}{|c|}{ Real average return (geometric) since 2003(2)- Euro } & & $7.1 \%$ & $5.0 \%$ & $2.3 \%$ \\
\hline
\end{tabular}




\begin{tabular}{|c|c|c|c|c|c|c|}
\hline \multicolumn{7}{|l|}{ Panel B (in USD) } \\
\hline \multirow[b]{2}{*}{ Year (semester) } & \multicolumn{3}{|c|}{ Nominal returns } & \multicolumn{3}{|c|}{ Index values } \\
\hline & White & Colored & Other Gems & White & Colored & Other Gems \\
\hline 1999(1) & & & & $100.0 \%$ & $100.0 \%$ & $100.0 \%$ \\
\hline 1999(2) & $15.5 \%$ & $47.6 \%$ & $-18.6 \%$ & $115.5 \%$ & $147.6 \%$ & $81.4 \%$ \\
\hline $2000(1)$ & $0.5 \%$ & $-34.6 \%$ & $-0.2 \%$ & $116.1 \%$ & $96.6 \%$ & $81.2 \%$ \\
\hline $2000(2)$ & $-5.7 \%$ & $38.8 \%$ & $-5.7 \%$ & $109.5 \%$ & $134.1 \%$ & $76.6 \%$ \\
\hline 2001(1) & $7.3 \%$ & $-11.6 \%$ & $8.7 \%$ & $117.5 \%$ & $118.5 \%$ & $83.3 \%$ \\
\hline 2001(2) & $-7.0 \%$ & $-21.4 \%$ & $0.6 \%$ & $109.3 \%$ & $93.2 \%$ & $83.8 \%$ \\
\hline 2002(1) & $0.3 \%$ & $7.3 \%$ & $4.5 \%$ & $109.6 \%$ & $100.0 \%$ & $87.6 \%$ \\
\hline $2002(2)$ & $-0.1 \%$ & $-2.9 \%$ & $-32.6 \%$ & $109.5 \%$ & $97.1 \%$ & $59.0 \%$ \\
\hline 2003(1) & $-6.8 \%$ & $-6.2 \%$ & $32.9 \%$ & $102.0 \%$ & $91.1 \%$ & $78.4 \%$ \\
\hline $2003(2)$ & $10.8 \%$ & $35.3 \%$ & $33.3 \%$ & $113.0 \%$ & $123.3 \%$ & $104.5 \%$ \\
\hline $2004(1)$ & $1.6 \%$ & $-4.9 \%$ & $-8.9 \%$ & $114.8 \%$ & $117.2 \%$ & $95.2 \%$ \\
\hline 2004(2) & $12.8 \%$ & $28.5 \%$ & $22.2 \%$ & $129.5 \%$ & $150.6 \%$ & $116.3 \%$ \\
\hline $2005(1)$ & $20.5 \%$ & $11.8 \%$ & $-2.6 \%$ & $156.1 \%$ & $168.4 \%$ & $113.3 \%$ \\
\hline $2005(2)$ & $3.1 \%$ & $13.2 \%$ & $-22.0 \%$ & $161.0 \%$ & $190.7 \%$ & $88.4 \%$ \\
\hline $2006(1)$ & $14.7 \%$ & $-5.5 \%$ & $19.8 \%$ & $184.6 \%$ & $180.2 \%$ & $105.9 \%$ \\
\hline $2006(2)$ & $6.8 \%$ & $-6.7 \%$ & $-19.9 \%$ & $197.1 \%$ & $168.2 \%$ & $84.8 \%$ \\
\hline $2007(1)$ & $14.7 \%$ & $17.6 \%$ & $50.7 \%$ & $226.0 \%$ & $197.8 \%$ & $127.8 \%$ \\
\hline $2007(2)$ & $10.7 \%$ & $17.1 \%$ & $-0.3 \%$ & $250.2 \%$ & $231.6 \%$ & $127.4 \%$ \\
\hline $2008(1)$ & $40.3 \%$ & $-1.9 \%$ & $17.7 \%$ & $351.1 \%$ & $227.2 \%$ & $149.9 \%$ \\
\hline $2008(2)$ & $-25.1 \%$ & $-21.7 \%$ & $-34.6 \%$ & $263.1 \%$ & $177.8 \%$ & $98.1 \%$ \\
\hline $2009(1)$ & $-12.4 \%$ & $1.8 \%$ & $-15.8 \%$ & $230.4 \%$ & $181.0 \%$ & $82.6 \%$ \\
\hline $2009(2)$ & $5.0 \%$ & $11.7 \%$ & $115.9 \%$ & $241.9 \%$ & $202.1 \%$ & $178.3 \%$ \\
\hline 2010(1) & $12.1 \%$ & $0.7 \%$ & $12.3 \%$ & $271.1 \%$ & $203.5 \%$ & $200.3 \%$ \\
\hline $2010(2)$ & $-1.6 \%$ & $9.6 \%$ & $-45.3 \%$ & $266.8 \%$ & $223.1 \%$ & $109.6 \%$ \\
\hline 2011(1) & $11.6 \%$ & $15.6 \%$ & $157.8 \%$ & $297.8 \%$ & $257.8 \%$ & $282.6 \%$ \\
\hline 2011(2) & $0.7 \%$ & $3.3 \%$ & $-37.6 \%$ & $299.8 \%$ & $266.2 \%$ & $176.4 \%$ \\
\hline 2012(1) & $3.6 \%$ & $-16.8 \%$ & & $310.7 \%$ & $221.6 \%$ & \\
\hline 2012(2) & $-7.8 \%$ & $18.3 \%$ & & $286.5 \%$ & $262.2 \%$ & \\
\hline \multicolumn{3}{|c|}{ Nominal average return (geometric) since 1999(1) - USD } & & $8.1 \%$ & $7.4 \%$ & $4.7 \%$ \\
\hline \multicolumn{3}{|c|}{ Nominal average return (geometric) since 2003(2) - USD } & & $10.9 \%$ & $8.7 \%$ & $6.8 \%$ \\
\hline \multicolumn{3}{|c|}{ Real average return (geometric) since 1999(1)- USD } & & $5.5 \%$ & $4.8 \%$ & $2.1 \%$ \\
\hline \multicolumn{3}{|c|}{ Real average return (geometric) since 2003(2) - USD } & & $8.2 \%$ & $6.1 \%$ & $4.1 \%$ \\
\hline
\end{tabular}




\section{Macrothink}

\section{Comparison with Other Assets}

Table 4 is instructive, but it is hard to evaluate the financial attractiveness of diamonds and gems without a proper benchmark. In Figure 3, we depict the index values of white and colored diamonds, other gems, and other types of assets such as US and European stocks (S\&P500 and Eurostoxx600), gold (S\&P Goldman Sachs Gold Index), European government and corporate bonds (Meryll Lynch), real estate (Case Shiller Composite 10 from the C-S US National Real Estate Index and the S\&P EU REIT index) for each semester over the period 1999-2012. All index values are in nominal terms, and each index is set equal to 100 for the first half of 1999. To deflate our nominal returns, we use the US consumer price index (from the Bureau of Labor Statistics) and the Harmonized Index of Consumer Prices (Eurostat).

Figure 3. Index values of various asset classes

Figure 3 shows the index values in nominal Euro for white diamonds, colored diamonds, other gems, US and European stocks (S\&P500 and Eurostoxx600), European government and corporate bonds (Meryll Lynch indices ML EU GOV and ML EU CORP), real estate (Case Shiller Composite 10 index) for each semester over the period 1999-2012. The returns for white and colored diamonds are shown in Table 4. In all cases, the index is set equal to 100 in the first semester of 1999.

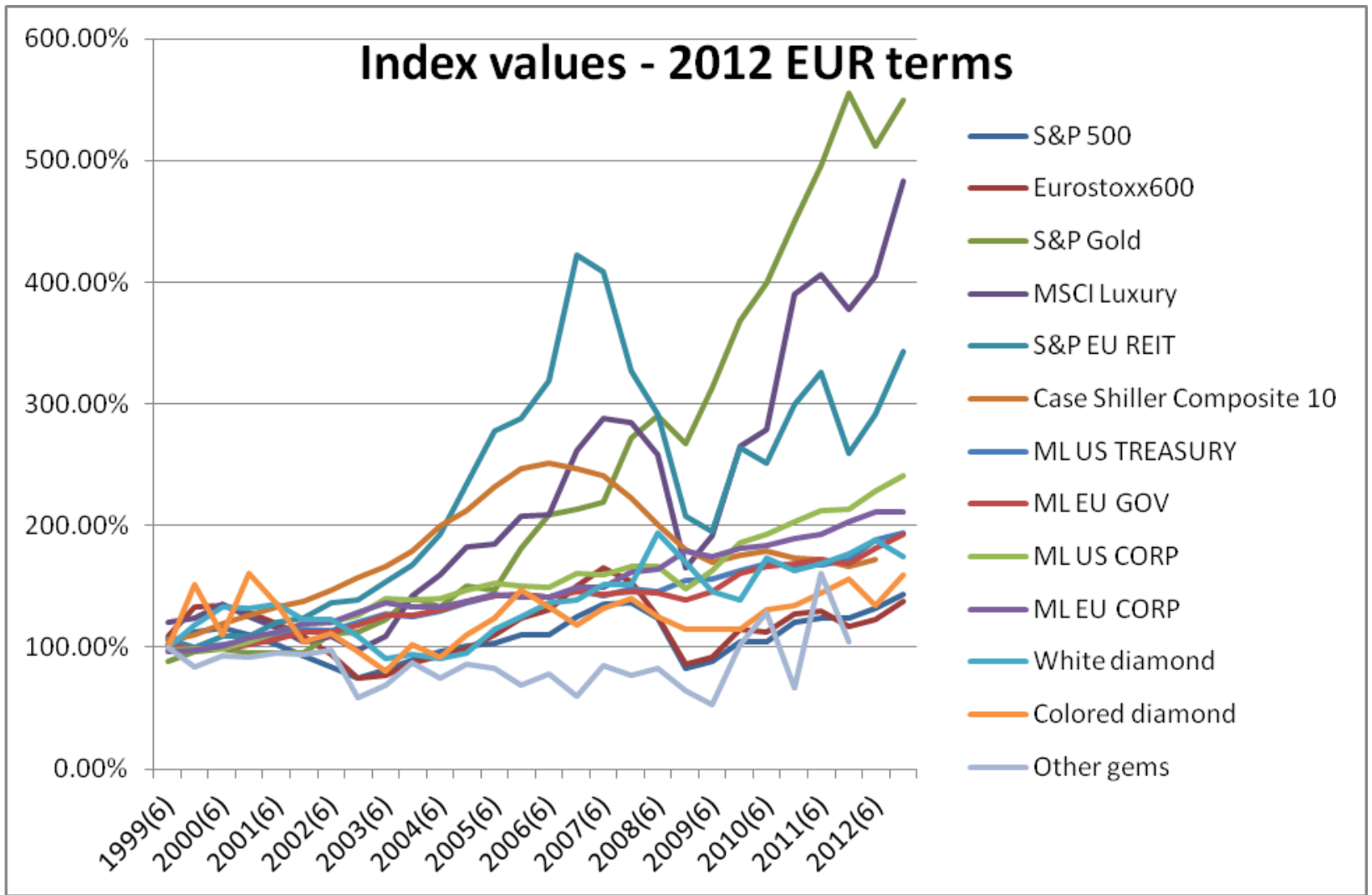


Figure 3 shows that white diamonds outperformed financial assets between early-1999 and late-2012 with exception of US real estate of which the index clearly reflects the bubble (until 2007). Similarly, colored diamonds performed better than stocks and as bonds. Gold appreciated still faster than investment-grade gems. Of course, gold has increased its status of a safe haven since the deep financial crisis that started in 2007.

Figure 3 also further illustrates that shocks in the equity market often precede changes in the gem market. For example, the financial crisis struck in the second half of 2007, but only translated into lower diamond prices in the second semester of 2008.

In Table 5, we more formally compare the performance of white and colored diamonds with that of financial assets, real estate and gold since the first half of 1999 . We show the annualized returns, the annualized standard deviation, ${ }^{2}$ and an estimate of the Sharpe ratio (i.e., the return in excess of the risk free rate by unit of risk) for each asset. ${ }^{3}$ Moreover, we include the correlation of each asset with same-period and previous-period global stock returns.

White diamonds appreciated by an annualized nominal return of $6.9 \%$ (in Euro) or $8.11 \%$ (in USD) between 1999 and 2012 (Panel A of Table 5), whereas the returns on stocks merely reached $0.6 \%$ (Europe) or $1.3 \%$ due to the multiple equity market crises (the bursting of the dot.com bubble in 2000 and the succession of crises since 2007 - including the property market, banking, and government debt crises). Over this period, investment in bonds (5\%-5.5\% for government bonds and 5\%-6.5\% for corporate bonds) beat stocks but not white or colored diamonds. An investment in short-term government paper turned out not to be a bad investment relative to stocks, and long term government and corporate bonds and even real estate (Panel A). However, the investment that beat even the diamond investment was gold with a nominal annual return of $12.91 \%$. Even when excluding the financial crises since 2007, Panel B does not show a strikingly different picture, save that real estate was an attractive investment (because of its exaggerated growth). Panels $C$ and D of Table 5 give the risk and returns of all asset classes in real terms.

\footnotetext{
${ }^{2}$ The annualized standard deviation is calculated by multiplying the standard deviation over the half-yearly returns by the square root of two.

${ }^{3}$ We consider returns before transaction costs; these costs are of course higher for gems than for financial assets.
} 
Table 5. Return and risk of investments in diamonds and other assets

Table 5 provides information on the mean nominal and real returns (and their standard deviations) for Euro and USD investors for white and colored diamonds, stocks (S\&P500, Eurostoxx600), gold (S\&P gold), luxury investments (MSCI Luxury Investment index), real estate (Cash-Shiller Composite 10 index, and real estate investment trusts for Europe (S\&P EU REITs)), European and American government and corporate bonds (Meryll Lynch indices), and short-term government bonds (US T-bills on 6 months, German bonds on 6 months). All calculations are based on half-yearly returns over the period 1999-2012. The returns for white and colored diamonds are shown in Table 4. Data on the returns of global stocks, global government bonds, and gold were downloaded from Global Financial data.

\begin{tabular}{|c|c|c|c|c|c|}
\hline $\begin{array}{l}\text { Panel A } \\
1999-2012\end{array}$ & Currency & $\begin{array}{l}\text { Annual } \\
\text { Nominal } \\
\text { mean returns }\end{array}$ & $\begin{array}{l}\text { Annualized } \\
\text { stand. dev. }\end{array}$ & $\begin{array}{l}\text { Sharpe } \\
\text { ratio }\end{array}$ & \begin{tabular}{|l|} 
Correlation \\
with stock \\
returns
\end{tabular} \\
\hline \multicolumn{6}{|l|}{ Diamonds } \\
\hline White diamond & USD & $8.11 \%$ & $17.39 \%$ & 0.188 & 0.307 \\
\hline White diamond & EUR & $6.86 \%$ & $17.04 \%$ & 0.071 & 0.128 \\
\hline Colored diamond & USD & $7.40 \%$ & $27.09 \%$ & 0.094 & 0.369 \\
\hline Colored diamond & EUR & $6.13 \%$ & $27.56 \%$ & 0.017 & 0.362 \\
\hline \multicolumn{6}{|l|}{ Stocks } \\
\hline US (S\&P500) & USD & $1.30 \%$ & $16.28 \%$ & -0.218 & 1.000 \\
\hline Europe (Eurostoxx600) & EUR & $0.58 \%$ & $19.28 \%$ & -0.263 & 1.000 \\
\hline \multicolumn{6}{|l|}{ Gold } \\
\hline Gold (S\&P) & USD & $12.91 \%$ & $15.38 \%$ & 0.524 & 0.491 \\
\hline \multicolumn{6}{|l|}{ Luxury and real estate } \\
\hline Luxury investments (MSCI) & USD & $10.40 \%$ & $24.85 \%$ & 0.223 & 0.912 \\
\hline US real estate (Case-Shiller) & USD & $3.74 \%$ & $8.34 \%$ & -0.133 & 0.274 \\
\hline European Real estate (EU REITs) & EUR & $3.49 \%$ & $21.63 \%$ & -0.100 & 0.647 \\
\hline \multicolumn{6}{|l|}{ Bonds - long term } \\
\hline US Gov. Bonds (ML) & USD & $5.48 \%$ & $4.80 \%$ & 0.131 & -0.606 \\
\hline US Corp. Bonds (ML) & USD & $6.50 \%$ & $6.92 \%$ & 0.238 & 0.556 \\
\hline EU Gov. Bonds (ML) & EUR & $4.96 \%$ & $4.28 \%$ & -0.161 & -0.242 \\
\hline EU Corp. Bonds (ML) & EUR & $4.86 \%$ & $4.70 \%$ & -0.168 & 0.289 \\
\hline \multicolumn{6}{|l|}{ Risk-free assets } \\
\hline US T-bills 6 months & USD & $4.85 \%$ & $2.83 \%$ & NA & -0.137 \\
\hline German ST Bonds 6 months & EUR & $5.65 \%$ & $1.85 \%$ & NA & -0.586 \\
\hline $\begin{array}{l}\text { Table } 5 \text { continued } \\
\text { Panel B }\end{array}$ & Currency & $\begin{array}{c}\text { Annual } \\
\text { Nominal }\end{array}$ & $\begin{array}{l}\text { Annualized } \\
\text { stand. dev. }\end{array}$ & $\begin{array}{l}\text { Sharpe } \\
\text { ratio }\end{array}$ & $\begin{array}{c}\text { Correlation } \\
\text { with stock }\end{array}$ \\
\hline
\end{tabular}




\begin{tabular}{|c|c|c|c|c|c|}
\hline 1999-2007 & & mean return & & & returns \\
\hline \multicolumn{6}{|l|}{ Diamonds } \\
\hline White diamond & USD & $11.39 \%$ & $11.95 \%$ & 0.665 & 0.526 \\
\hline White diamond & EUR & $7.73 \%$ & $14.28 \%$ & 0.316 & 0.598 \\
\hline Colored diamond & USD & $10.39 \%$ & $31.30 \%$ & 0.222 & 0.249 \\
\hline Colored diamond & EUR & $6.73 \%$ & $33.14 \%$ & 0.106 & 0.431 \\
\hline \multicolumn{6}{|l|}{ Stocks } \\
\hline S\&P500 & USD & $2.53 \%$ & $10.28 \%$ & -0.089 & 1 \\
\hline Eurostoxx600 & EUR & $3.95 \%$ & $16.25 \%$ & 0.045 & 1 \\
\hline \multicolumn{6}{|l|}{ Gold } \\
\hline S\&P Gold & USD & $11.38 \%$ & $14.18 \%$ & 0.560 & 0.139 \\
\hline \multicolumn{6}{|l|}{ Luxury and real estate } \\
\hline MSCI Luxury & USD & $11.48 \%$ & $16.95 \%$ & 0.474 & 0.797 \\
\hline Case Shiller Composite 10 & USD & $8.93 \%$ & $6.59 \%$ & 0.833 & -0.02 \\
\hline S\&P EU REIT & EUR & $8.43 \%$ & $17.13 \%$ & 0.304 & 0.261 \\
\hline \multicolumn{6}{|l|}{ Bonds - long term } \\
\hline ML US Gov & USD & $5.49 \%$ & $4.71 \%$ & 0.435 & -0.58 \\
\hline ML US Corp & USD & $5.89 \%$ & $5.02 \%$ & 0.488 & -0.396 \\
\hline ML EU Gov & EUR & $4.57 \%$ & $4.20 \%$ & 0.321 & -0.396 \\
\hline ML EU Corp & EUR & $4.37 \%$ & $3.90 \%$ & 0.295 & -0.411 \\
\hline \multicolumn{6}{|l|}{ Risk-free assets } \\
\hline Tbill-6m & USD & $3.44 \%$ & $1.69 \%$ & NA & -0.018 \\
\hline GER-6m & EUR & $3.22 \%$ & $0.92 \%$ & NA & -0.516 \\
\hline
\end{tabular}




\begin{tabular}{|c|c|c|c|c|c|}
\hline 1999-2012 & Currency & $\begin{array}{c}\text { Annualized } \\
\text { Real } \\
\text { mean return }\end{array}$ & $\begin{array}{l}\text { Annualized } \\
\text { std. dev. }\end{array}$ & $\begin{array}{l}\text { Sharpe } \\
\text { ratio }\end{array}$ & $\begin{array}{c}\text { Correlation with } \\
\text { stock returns }\end{array}$ \\
\hline \multicolumn{6}{|l|}{ Diamonds } \\
\hline White diamond & USD & $5.51 \%$ & $16.29 \%$ & 0.343 & 0.269 \\
\hline White diamond & EUR & $4.21 \%$ & $16.39 \%$ & 0.181 & 0.131 \\
\hline Colored diamond & USD & $4.82 \%$ & $26.63 \%$ & 0.184 & 0.359 \\
\hline Colored diamond & EUR & $3.50 \%$ & $27.24 \%$ & 0.083 & 0.367 \\
\hline \multicolumn{6}{|l|}{ Stocks } \\
\hline S\&P500 & USD & $-3.87 \%$ & $17.28 \%$ & -0.219 & 1 \\
\hline Eurostoxx600 & EUR & $-2.66 \%$ & $19.89 \%$ & -0.197 & 1 \\
\hline \multicolumn{6}{|l|}{ Gold } \\
\hline S\&P Gold & USD & $7.58 \%$ & $16.00 \%$ & 0.479 & 0.543 \\
\hline \multicolumn{6}{|l|}{ Luxury and real estate } \\
\hline MSCI Luxury & USD & $4.83 \%$ & $25.96 \%$ & 0.189 & 0.923 \\
\hline Case Shiller Composite 10 & USD & $-1.28 \%$ & $8.58 \%$ & -0.140 & 0.379 \\
\hline S\&P EU REIT & EUR & $0.21 \%$ & $22.07 \%$ & -0.047 & 0.663 \\
\hline \multicolumn{6}{|l|}{ Bonds - long term } \\
\hline ML US Gov & USD & $0.45 \%$ & $4.53 \%$ & 0.117 & -0.393 \\
\hline ML US Corp & USD & $1.36 \%$ & $7.97 \%$ & 0.181 & 0.632 \\
\hline ML EU GOV & EUR & $1.83 \%$ & $4.33 \%$ & 0.134 & -0.101 \\
\hline ML EU Corp & EUR & $1.71 \%$ & $5.14 \%$ & 0.090 & 0.388 \\
\hline \multicolumn{6}{|l|}{ Risk-free assets } \\
\hline Tbill-6m & USD & $-0.08 \%$ & $1.82 \%$ & NA & 0.222 \\
\hline GER-6m & EUR & $1.25 \%$ & $1.20 \%$ & NA & -0.304 \\
\hline
\end{tabular}




\begin{tabular}{|c|c|c|c|c|c|}
\hline $\begin{array}{l}\text { Table } 5 \text { continued } \\
\text { Panel D } \\
\text { 1999-2007 }\end{array}$ & Currency & $\begin{array}{l}\text { Annualized } \\
\text { mean return }\end{array}$ & $\begin{array}{l}\text { Annualized } \\
\text { std. dev. }\end{array}$ & $\begin{array}{l}\text { Sharpe } \\
\text { ratio }\end{array}$ & $\begin{array}{l}\text { Correlation with } \\
\text { stock returns }\end{array}$ \\
\hline \multicolumn{6}{|l|}{ Diamonds } \\
\hline White diamond & USD & $8.36 \%$ & $11.59 \%$ & 0.656 & 0.51 \\
\hline White diamond & EUR & $4.98 \%$ & $13.99 \%$ & 0.232 & 0.603 \\
\hline Colored diamond & USD & $7.39 \%$ & $30.87 \%$ & 0.215 & 0.254 \\
\hline Colored diamond & EUR & $4.01 \%$ & $32.74 \%$ & 0.069 & 0.437 \\
\hline \multicolumn{6}{|l|}{ Stocks } \\
\hline S\&P500 & USD & $-2.85 \%$ & $10.23 \%$ & -0.353 & 1 \\
\hline Eurostoxx600 & EUR & $0.89 \%$ & $16.50 \%$ & -0.052 & 1 \\
\hline \multicolumn{6}{|l|}{ Gold } \\
\hline S\&P Gold & USD & $5.77 \%$ & $14.15 \%$ & 0.354 & 0.132 \\
\hline \multicolumn{6}{|l|}{ Luxury and real estate } \\
\hline MSCI Luxury & USD & $5.80 \%$ & $17.10 \%$ & 0.295 & 0.805 \\
\hline Case Shiller Composite 10 & USD & $3.37 \%$ & $6.85 \%$ & 0.381 & -0.003 \\
\hline S\&P EU REIT & EUR & $5.31 \%$ & $17.21 \%$ & 0.207 & 0.274 \\
\hline \multicolumn{6}{|l|}{ Bonds - long term } \\
\hline ML US Gov & USD & $0.04 \%$ & $4.71 \%$ & -0.153 & -0.594 \\
\hline ML US Corp & USD & $0.43 \%$ & $5.04 \%$ & -0.066 & -0.406 \\
\hline ML EU GOV & EUR & $1.57 \%$ & $4.19 \%$ & -0.041 & -0.333 \\
\hline ML EU Corp & EUR & $1.37 \%$ & $3.90 \%$ & -0.095 & -0.343 \\
\hline \multicolumn{6}{|l|}{ Risk-free assets } \\
\hline Tbill-6m & USD & $0.76 \%$ & $1.45 \%$ & NA & -0.097 \\
\hline GER-6m & EUR & $1.74 \%$ & $0.87 \%$ & NA & -0.373 \\
\hline
\end{tabular}


Obviously, a performance evaluation needs to be combined with risk. The Sharpe ratio gives the return (over and above the risk free rate) by unit of risk. We learn from Panel A that white diamonds have since 1999 substantially outperformed stocks, US and European real estate, US government bonds, and European government and corporate bonds. Only the reward-to-variability ratio of US corporate bonds and the MSCI index of luxury investments was somewhat better, as was the Sharpe ratio of gold which was by far the outperforming investments because of its safe haven status in times of crisis. ${ }^{4}$ If we exclude the recent financial crises since 2007 (Panel B), we find that the Sharpe ratio of white diamonds (in USD) is far superior than that of stocks and bonds and even surpasses that of gold. We conclude that investments in diamonds may also maintain their value in times of crisis and give a fair return relative to its riskiness.

Table 5 also shows that the price changes of diamonds are positively correlated with equity market returns. This confirms the existence of a stock market wealth effect: the acquisition of diamonds is impacted by the evolution of equity wealth. (A similar observation that equity markets have wealth effects on collectibles prices is made by Goetzmann et al. (2011) in the context of the art market.) Our results thus shed doubt on the statement of an auction house jewelry specialist in July 2008 that "when stock markets go down, it's always good for us" (Bloomberg, 2008), which would suggest a negative correlation between the diamond and equity markets. Still, over the whole period 1999-2012, the correlation is between 0.13 (white diamonds) and 0.37 (coloured diamonds) which indicates that in a equity portfolio context, adding an investments in investment-grade diamonds still brings about some diversification advantages.

\section{Top Quality Stones}

An interesting question is whether the highest-end objects appreciate faster in value than the market as a whole. We therefore repeat the estimation of our hedonic model, first using all white diamonds of color categories D, E, and F, and second using all of those diamonds that weigh at least 10 carat. We illustrate the findings in Figure 4.

\footnotetext{
${ }^{4}$ It is important to note that the raw standard deviations may slightly underestimate the true riskiness of diamond investments, due to the time aggregation of data. We do not go deeper into this issue here, but refer to Renneboog and Spaenjers (2013).
} 
Figure 4. Top quality diamonds

Figure 4 shows the index values in deflated Euro (Figure 4a) and USD (Figure 4b) for (i) white diamonds, (ii) white diamonds of color categories D, E, and F, and (iii) white diamonds of color categories D, E, and F of at least 10 carat, for each semester over the period 1999-2012. The baseline returns for white diamonds are shown in Table 4. The other returns follow from a re-estimation of hedonic regression equation (1). In all cases, the index is set equal to 100 in the first semester of 1999.

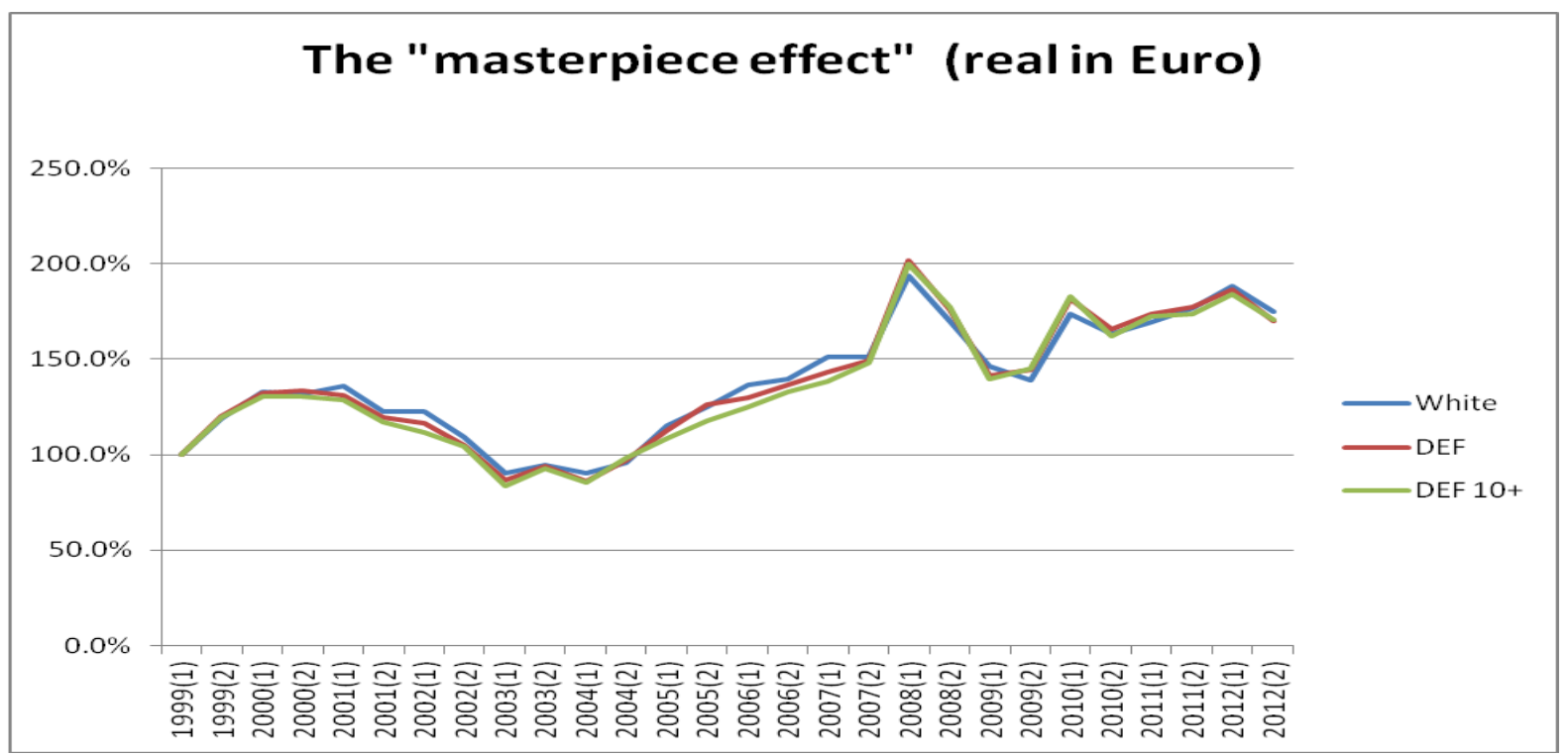

Figure $4 \mathrm{a}$

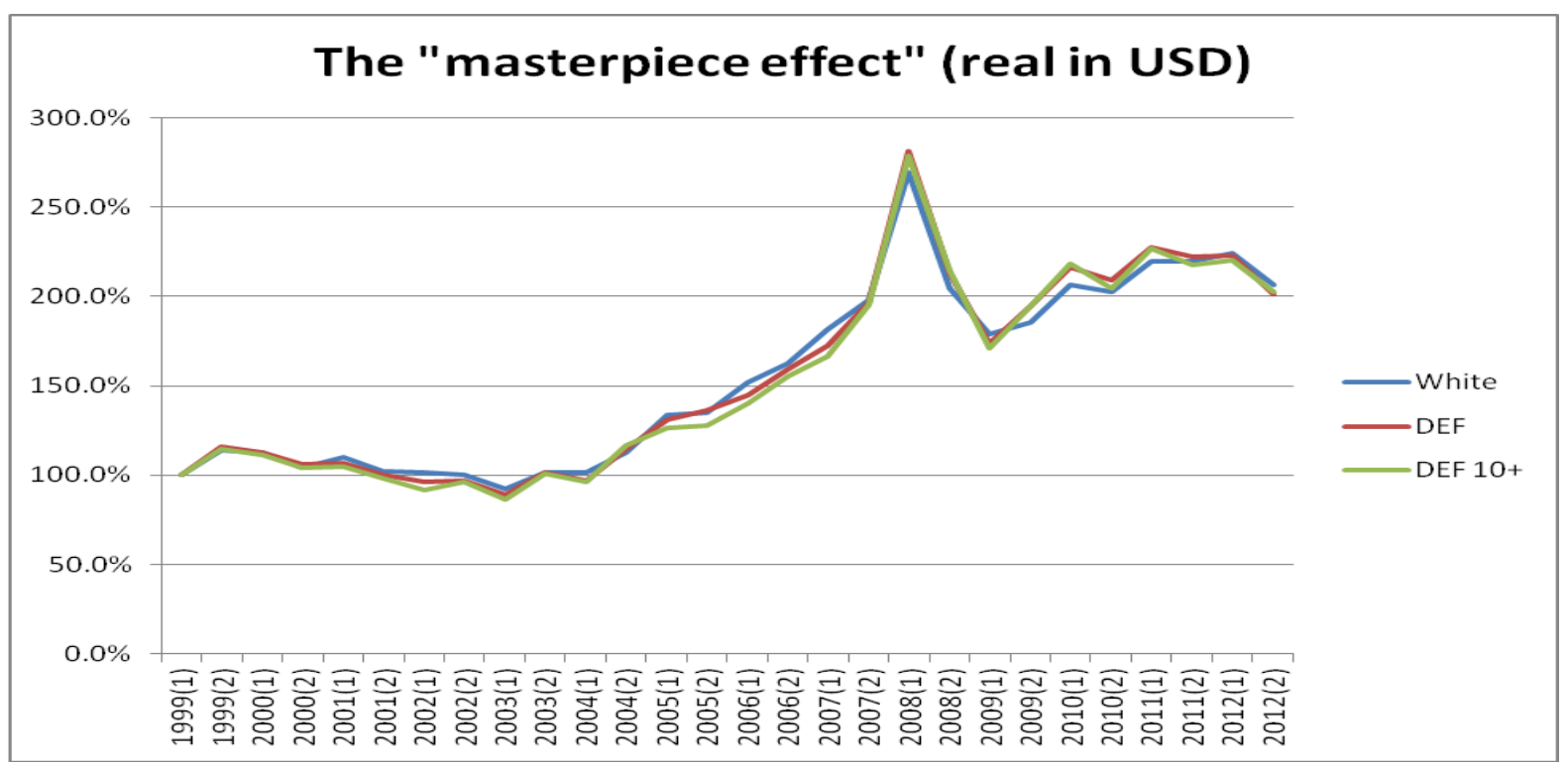

Figure $4 b$

There seems to be a small return premium for top-quality objects. Over our time frame, we find an annualized return of $5.9 \%$ for the larger white diamonds of categories D, E, and F (not reported), compared to $5.2 \%$ for our baseline series. This backs up previous evidence on the art market that higher returns can be realized on "masterpieces" (Renneboog and Spaenjers, 
2013). Yet, just like high-quality art works, top-end diamonds have slightly more volatile price paths.

\section{Conclusion and Discussion}

In this paper, we study the market for investment-grade gems between 1999 and 2012 . Applying a hedonic regression to a unique data set of auction transactions, we confirm that 'the four Cs' indeed play an important role in setting white diamond prices; overall, we are able to explain more than $95 \%$ of their price variation. Our model also performs well for colored diamonds and other gems (sapphires, rubies, and emeralds).

Over the past fourteen years, the annual nominal USD returns for white and colored diamonds amount to $8.1 \%$ and $7.4 \%$, respectively, or $5.5 \%$ and $4.8 \%$ over and above inflation. For a Euro investor, those returns are about $1.3 \%$ lower but still beat inflation by $3.5 \%$ annually. The returns for Other Gem types (rubies, emeralds and sapphires) are more volatile and somewhat lower (4.5\% nominal and $2.1 \%$ in real terms).

Although the diamond returns since 1999 have been below those on gold (a much-used safe haven in the recent financial crisis), both white and colored diamonds have significantly outperformed the US and European stock markets, US and European real estate, US government bonds, as well as European government and corporate bonds. The reward-to-risk of white diamonds has been very close to that of US corporate government bonds. The highest Sharpe ratio (by far) over the past 14 years was the one on gold. Still, in times of crisis investments in diamonds have shown an attractive risk-return tradeoff. We have also shown that in spite of a positive correlation between the diamond and the equity market, adding diamonds to an equity portfolio still have some diversification advantages.

One important issue to keep in mind is the low performance and high volatility of financial markets in the period examined in this paper. Ideally, it is important to compare the price trends of diamonds with that of financial assets and real assets over longer time periods. More research is needed to get a truly long-term picture of the realizable investment performance of gems.

\section{References}

Bloomberg (2008). Diamonds attract funds as largest gem price surge $76 \%$ in a year. 14 July 2008.

Capgemini (2010). World Wealth Report. Capgemini and Merrill Lynch Global Wealth Management.

Combris, P., Lecocq, S., \& Visser, M. (1997). Estimation for a hedonic price equation for Bordeaux wine: Does quality matter? Economic Journal. 170 (390-402). http://dx.doi.org/10.1111/j.0013-0133.1997.165.x

Dimson, E., \& Spaenjers, C. (2011). Ex post: The investment performance of collectible stamps. Journal of Financial Economics. $100 \quad$ (443-458). http://dx.doi.org/10.1016/j.jfineco.2010.12.005 
Dohrmann, B. (1981). Grow Rich with Diamonds: Investing in the World's Most Precious Gems. Harbor Publishing, San Francisco.

Dundek, M. (2009). Diamonds. Noble Gems Publications.

Goetzmann, W., Renneboog, L.\& Spaenjers, C. (2011). Art and Money, American Economic Review. 101(222-226). http://dx.doi.org/10.1257/aer.101.3.222

Ibbotson, R. \& Brinson, G. (1993). Global investing: The Professional's Guide to the World Capital Markets. McGraw-Hill, New York.

KPMG (2010). The Global Gems and Jewellery Industry - Vision 2015: Transforming for Growth.

Meese, R. A., \& Wallace, N. E. (1997). The construction of residential housing prices indices: A comparison of repeat-sales, hedonic regression and hybrid approaches. Journal of Real Estate Finance and Economics. 14 (51-73). http://dx.doi.org/10.1023/A:1007715917198

National Gemstone (2010). Retail gemstone trends (1975-2009) [http://www.preciousgemstones.com].

Renneboog, L., \& Spaenjers, C. (2013). Buying Beauty: On Prices and Returns in the Art Market, Management Science. 59 (36-53). http://dx.doi.org/10.1287/mnsc.1120.1580

Renneboog, L., \& Spaenjers, C. (2012). Hard Assets: The Returns on Rare Diamonds and Gems, Finance Research Letters. 9 (220-230). http://dx.doi.org/10.1016/j.frl.2012.07.003

Reuters (2010). Pink diamond record price shows market strength. 17 November 2010.

Scott, F., \& Yelowitz, A. (2010). Pricing anomalies in the market for diamonds: Evidence of conformist behaviour. Economic Inquiry. $48 \quad$ (353-368). http://dx.doi.org/10.1111/j.1465-7295.2009.00237.x

Spar, D. L. (2006). Continuity and change in the international diamond market. Journal of Economic Perspectives. 20 (195-208). http://dx.doi.org/10.1257/jep.20.3.195

Sutton, A. C. (1979). The Diamond Connection: A Manual for Investors. JD Press.

\section{Copyright Disclaimer}

Copyright for this article is retained by the author(s), with first publication rights granted to the journal.

This is an open-access article distributed under the terms and conditions of the Creative Commons Attribution license (http://creativecommons.org/licenses/by/3.0/). 